\title{
Regulatory role of BMP2 and BMP7 in spermatogonia and Sertoli cell proliferation in the immature mouse
}

\author{
Rossella Puglisi, Micaela Montanari, Pieranna Chiarella, Mario Stefanini and Carla Boitani \\ Department of Histology and Medical Embryology, University of Rome 'La Sapienza', Rome, Italy \\ (Correspondence should be addressed to Dr Carla Boitani, Department of Histology and Medical Embryology, University of Rome 'La Sapienza', \\ via A. Scarpa 14, 00161 Rome, Italy; Email: carla.boitani@uniroma1.it)
}

\begin{abstract}
Aim: The aim of this study was to determine the action of bone morphogenetic proteins (BMPs) on testicular cell proliferation during early postnatal life, a definite developmental time at which crucial changes in germ cell and Sertoli cell maturation occur.

Methods: We investigated the effect of BMP2 and BMP7, two factors which belong to the relatively distant decapentaplegic (DPP) and 60A classes of the large BMP family, upon spermatogonial and Sertoli cell proliferation, and we examined the expression of activin/BMP type II and type I receptors. We used in vitro cultured testis fragments from 7-day-old mice, highly purified populations of somatic and germ cells and total testes from mice of different ages. Cell proliferation was assessed by BrdU labelling and $\left[{ }^{3} \mathrm{H}\right]$-thimidine incorporation. Ribonuclease protection assays and Northern blotting were performed to analyse receptor expression.

Results and conclusions: We have demonstrated a stimulatory action of BMP2 and BMP7 in spermatogonia and Sertoli cell proliferation respectively. ActRIIB is the type II receptor expressed most in spermatogonia, whereas Sertoli cells specifically expressed BMPRIIB, in addition to ActRIIB. By contrast, the presence of ActRIIA was undetectable in either germ or somatic cells. The type I receptors ActRIA, ActRIB and BMPRIA were all found in both cell types, indicating that the observed effect of BMP 2 and BMP7 on testicular cell proliferation may be mediated by a number of combinatorial interactions in the receptor complexes. These findings suggest that BMPs are involved in physiological paracrine signalling during the first wave of spermatogenesis.
\end{abstract}

European Journal of Endocrinology 151 511-520

\section{Introduction}

The precise orchestration of mammalian spermatogenesis relies on the functional coordination of the Sertoli cell and germ cell lineages. This concept is apparent particularly during early postnatal testis development, when the final size of Sertoli cell population is being established and the first series of spermatogonial divisions occur. The importance of these developmental processes in determining the ultimate sperm output in the adult is supported by a considerable body of data (1). However, the regulatory mechanisms underpinning the coordinated spatial and temporal proliferation of Sertoli cells and germ cells are not yet fully understood. Both systemic hormones and local gonadal factors are involved in the control of somatic and germ cell events during the initiation of spermatogenesis. To date, a number of factors produced in the testis which act as mediators/modulators of gonadotrophin function have been identified. These factors include bone morphogenetic proteins (BMPs), which comprise a large group of secreted signalling molecules belonging to the transforming growth factor (TGF) $\beta$ superfamily
$(2,3)$. It is widely accepted that these proteins function as either homodimers or heterodimers, the latter being possibly even between members of relatively distant subfamilies such as the DPP class (BMP2 and BMP4) and 60A class (BMP5, BMP6, BMP7, BMP8A and BMP8B). Indeed, heterodimers composed of both classes are functionally more potent in vivo than homodimers, as has been shown in bone and mesoderm induction $(4,5)$.

Several $B M P$ genes are expressed in the testis. In particular, BMP7 and BMP8 $a / b$ transcripts have been found in germ cells at different stages of differentiation $(6,7)$, suggesting that not only Sertoli cells, but also germ cells secrete molecules mediating paracrine interactions in the testis. The role of BMP8 and BMP7 in spermatogenesis has so far been investigated by means of the knockout approach. About $50 \%$ of adult mice lacking $B M P 8 b$ had smaller testes as a result of progressive germ cell apoptosis and degeneration, which started in the primary spermatocyte stage and eventually led to sterility (8). Although less severe, a similar testicular phenotype was observed in BMP8anull mice (9). This phenotype was exacerbated in 
$B M P 8 a^{-1-}$ mutants that also lacked a single BMP7 allele (7), a fact which demonstrates the involvement of these BMPs in maintaining the spermatogenic function of the adult. BMP signalling is also required in the very early stages of germ cell development. In fact, genetic studies revealed that both $B M P 8 b^{-1-}$ and BMP $4^{-1-}$ mice lack primordial germ cells (PGC) $(10,11)$. Furthermore, in vitro co-culture experiments have shown that both BMP4 and BMP8B proteins function synergistically to induce PGC specification from the epiblast (12). BMP2, another member of the BMP family, acts in cooperation with BMP4 as a third signal in PGC formation (13). However, little information is available on the possible role played by these factors during early postnatal testis development.

An additional level of complexity in BMP signalling regulation is presented by the binding of homo- or heterodimeric BMP proteins to heteromeric receptor complexes that consist of structurally similar type I and type II subunits and display intrinsic serine/threonine kinase activity. Among the members of the large TGF $\beta$ superfamily receptors, several type I (activinlike kinase, ALK) and type II receptors have been described (14). The emerging overall picture, in which different combinations of receptors interact with different ligands of the TGF $\beta$ superfamily, points to a relatively high degree of promiscuity between various ligands and receptors. In accordance with this view, activin-like type II receptor (ActRIIA) can bind to both BMP7 and activin (15) and, in concert with ActRIA, ActRIB or BMPRIB, transduces BMP7 and activin signals (16). On the other hand, it was shown that BMP7 binds to BMPRIA (ALK3) and BMPRIB (ALK6) in cells cotransfected with DAF-4 as BMP type II receptor (17).

In the adult testis, ActRIIA and ActRIIB were localized in both germ cells at specific stages of maturation and somatic cells $(18-20)$, a fact which points to a potential role of these receptors in mediating activin and/or BMP signalling. Indeed, we have previously demonstrated that activin A regulates terminal Sertoli cell proliferation in the prepuberal rat testis and that this effect is mediated by ActRIIA $(21,22)$.

In this study, we have used the in vitro organ culture of testis fragments to address the issue of whether BMPs are directly involved in the control of germ cell and Sertoli cell proliferation in the early postnatal period of mouse testis development. We show that BMP2 and BMP7, two factors belonging to two different classes of the BMP family, exert a stimulatory effect on spermatogonia and Sertoli cell division respectively. We also analysed the spatiotemporal expression of BMP type II and type I receptors in both isolated germ and Sertoli cell preparations and in the whole developing testis, and showed that these receptors are differentially expressed in spermatogonia and Sertoli cells.

\section{Materials and methods}

\section{Animals}

Male CD1 mice were used in all experiments. Animals were housed in accordance with the guidelines for animal care of the University of Rome 'La Sapienza' and were killed by asphyxiation with $\mathrm{CO}_{2}$ before organ removal.

\section{Organ cultures}

In vitro organ cultures of testis from 7-day-old mice were performed as previously described $(21,23)$. Briefly, testicular fragments were placed on steel grids coated with $2 \%$ agar. Grids were then placed in organ culture dishes (Falcon, Becton Dickinson, NJ, USA). The culture medium used was Eagle's minimum essential medium with Earle's salts (Gibco BRL, Grand Island, NJ, USA) supplemented with glutamine (2 mM), HEPES (15 mM), nonessential amino acids (single-strength), penicillin $(100 \mathrm{IU} / \mathrm{ml})$, streptomycin $(100 \mathrm{mg} / \mathrm{ml})$ and gentamicin $(50 \mathrm{mg} / \mathrm{ml})$.

Ovine FSH (o-FSH-20, NHPP, Torrance, CA, USA), recombinant human BMP2 (Genetics Institute, Cambridge, MA, USA) and recombinant human BMP7 (Creative Biomolecules, Hopkinton, MA, USA) were added to the culture medium, either alone or in combination, at the concentrations indicated in the text. Tissue fragments were cultured at $32{ }^{\circ} \mathrm{C}$ in a humidified incubator with $5 \% \mathrm{CO}_{2}$ for 3 days and labelled with $5 \mu \mathrm{Ci} / \mathrm{ml}$ methyl- $\left[{ }^{3} \mathrm{H}\right]$-thymidine (spec. act. $20 \mathrm{Ci} / \mathrm{mmol}$, NEN Du Pont, Milan, Italy) or 5-bromodeoxyuridine during the last $5 \mathrm{~h}$ of culture (21), washed twice with minimum essential medium and processed as needed.

\section{Thymidine incorporation into DNA}

Determination of $\left[{ }^{3} \mathrm{H}\right]$-thymidine incorporation into testis fragments was performed as previously described (21). Briefly, labelled fragments were incubated overnight at $55^{\circ} \mathrm{C}$ in the presence of $0.5 \mathrm{mg} / \mathrm{ml}$ proteinase-K (Sigma) in $50 \mathrm{mM}$ Tris-HCl pH 8, $100 \mathrm{mM}$ EDTA, $100 \mathrm{mM} \mathrm{NaCl}$ and 1\% SDS. The DNA was then extracted with phenol-chloroform-isoamyl alcohol, and radioactivity was measured by liquid scintillation counting. The DNA content was determined by a fluorometric assay using Hoechst 33258 as fluorescent dye. To this end, aliquots of samples were added to an appropriate solution of the dye, and fluorescence was immediately determined with a Perkin-Elmer fluorometer at 365/460 nm (excitation/emission) wavelength, using salmon sperm DNA as standard.

\section{Bromodeoxyuridine incorporation}

BrdU-labelled testis fragments were fixed in Bouin's fluid, dehydrated, embedded in Histowax (ReichertJung, Milan, Italy) and serial-sectioned. Sections 
$(5 \mu \mathrm{m})$ were stained with an anti-BrdU monoclonal antibody diluted 1:10 (Amersham) and a peroxidaseconjugated secondary antimouse IgG antibody diluted 1:80 (DAKO, Milan, Italy).

\section{Morphological analysis}

Somatic and germ cells were identified by cell size, nuclear morphology and localization within the seminiferous cords, according to the descriptions by Huckins and Oakberg (24) and Russell et al. (25). The numbers of proliferating spermatogonia and Sertoli cells were determined by counting BrdU-labelled cells per $250000 \mu^{2}$ field in 30-40 cord cross-sections selected at random within each treatment.

\section{Cell isolation}

Highly purified type A spermatogonia were obtained from 7-day-old mouse testis as previously described (26). Briefly, the cell suspension obtained after enzymatic digestion of testicular tissue was plated for $1 \mathrm{~h}$ on plastic dishes coated with Datura stramonium agglutinin (DSA) (Sigma). Cells which did not adhere to the lectin were then fractionated on a discontinous percoll density gradient (Pharmacia Biotech, Milan, Italy), yielding a cell fraction containing 85-90\% type A spermatogonia (as assessed by c-Kit immunostaining). Pachytene spermatocytes and round spermatids were obtained from 28-30-day-old mouse testis as previously described (27). Purity of cell fractions was verified by morphological assessment of cytospinned stained cell preparations. Sertoli cell contamination in germ cell fractions was monitored by RPA analysis of FSH receptor expression. Sertoli cells were isolated from 7 - and 14-day-old mice as described by Scarpino et al. (28). Sertoli cell cultures appeared to contain less than $5 \%$ myoid cells, as determined by alkaline phosphatase staining, and less than $1 \%$ germ cells.

\section{Construction of probe plasmids}

Total RNA was extracted from tissues or isolated cells by the guanidinium thiocyanate-cesium chloride ultracentrifugation method (29).

cDNA fragments were amplified by RT-PCR from the following tissues: corticotrophic cell line AtT-20 for ActRIIA (bp 117-453) (30), NIH-3T3 for ActRIIB (bp 272-471 and 122-471) (31), NIH-3T3 for ActR-IA (bp 627-966) (32), 12-day postcoitum (dpc) mouse placenta for ActRIB (bp 116-403) (33), 12.5 dpc embryo for BMPRIA (bp 155-472) (34), adult mouse brain for BMPRII (bp 442-805) (35) and adult mouse testis for FSH receptor (bp 1510-1680, accession no. M87570). The ribosomal protein S 16 mRNA (bp 1799-1990) (36) was used as internal standard. All PCR products were cloned into pBluescript SK $(+)$ plasmid, and their sequences were confirmed.

\section{Ribonuclease protection assay (RPA)}

Run-off transcripts were synthesized from each linearized template with a Transcription in vitro System Kit (Promega). Antisense RNA probes were labelled with $\left[\alpha-{ }^{32}\right.$ P]UTP using T3, T7 or SP6 polymerase. Fulllength single-stranded RNA probes were purified by acrylamide gel electrophoresis. RPA was performed by the RPA II Kit (Ambion, Austin, TX, USA), using $20 \mu \mathrm{g}$ of total RNA and $3 \times 10^{5}$ c.p.m. of labelled probe for each reaction. Nuclease-resistant probes were visualized by gel electrophoresis [5\% acrylamide, $8 \mathrm{M}$ urea and $90 \mathrm{mM}$ Tris Borate, $2 \mathrm{mM}$ EDTA (TBE)] and autoradiography. To check riboprobe integrity, each RPA experiment was performed in parallel with the positive samples mentioned above. Control RPA experiments showed a $336 \mathrm{bp}$ band for ActRIIA (in ATt-20), $200 \mathrm{bp}$ and $339 \mathrm{bp}$ bands for ActRIIB and ActRIA respectively (in NIH-3T3), a 287 bp band for ActRIB (in $12 \mathrm{dpc}$ mouse placenta) and a $317 \mathrm{bp}$ band for BMPRIA (in $12 \mathrm{dpc}$ mouse embryo) (data not shown). Protected fragments of identical size were found when the riboprobes were hybridized with total RNA isolated from mouse testis or isolated spermatogonia and Sertoli cells.

The mRNA levels of various activin receptors were individually quantified by autoradiogram densitometric scanning and then normalized to the content of S16 and expressed as arbitrary densitometric units.

\section{Northern blot analysis}

RNA preparations were fractionated on a denaturating formaldehyde $1.2 \%$ agarose gel and then transferred to a nylon membrane (Hybond- ${ }^{+}$, Amersham). After prehybridization for $15 \mathrm{~h}$ at $42{ }^{\circ} \mathrm{C}$ in a solution containing $50 \%$ formamide, $1 \mathrm{M} \mathrm{NaCl}, 10 \%$ dextran sulphate, $0.2 \%$ Denhardt's solution, $1 \%$ SDS and $100 \mu \mathrm{g} / \mathrm{ml}$ denatured salmon sperm DNA, the blots were hybridized with a receptor-specific cDNA probe labelled with $\left[{ }^{32} \mathrm{P}\right]-$ dCTP by random priming (Gibco BRL). After hybridization at $42{ }^{\circ} \mathrm{C}$, the filters were washed several times with $2 \times \mathrm{SSC}, 0.1 \%$ SDS at room temperature for $30 \mathrm{~min}$. Washing duration $(1-3 \times 30 \mathrm{~min})$ and temperature $\left(50\right.$ or $60{ }^{\circ} \mathrm{C}$ ) depended on the probe used. The final wash was in $0.5 \times \mathrm{SSC}, 0.1 \%$ SDS at room temperature for $30 \mathrm{~min}$. Filters were eventually exposed to Hyperfilms-MP (Amersham) at $-80^{\circ} \mathrm{C}$ for the appropriate time. For standardization of different lanes, blots were rehybridized with ribosomal RNA cDNA probe.

\section{Statistics}

Comparison of $\left[{ }^{3} \mathrm{H}\right]$-thymidine incorporation between different treatments was performed by analysis of variance (ANOVA). Comparison of cell numbers between control and treated testicular fragments and comparison of receptor expression between two cell types was performed by Student's $t$-test. 


\section{Results}

\section{Effect of BMP2 and BMP7 on [3]-thymidine incorporation by in vitro cultured mouse testis fragments}

To investigate whether BMP7 (a factor belonging to the 60 A class of the BMP family) directly affects testicular cell growth and differentiation, we cultured testis fragments from 7-day-old mice for 3 days in the presence or absence of recombinant BMP7 with or without FSH (Fig. 1). FSH $(20 \mathrm{ng} / \mathrm{ml})$ significantly stimulated $\left[{ }^{3} \mathrm{H}\right]$ thymidine incorporation compared with the control, whereas BMP7 $(200 \mathrm{ng} / \mathrm{ml})$ had no effect. However, the combination of BMP7 with gonadotrophin resulted in a significant increase (1.5-fold) in $\left[{ }^{3} \mathrm{H}\right]$-thymidine incorporation compared with that observed with the FSH treatment alone. When increasing concentrations of BMP7 (from 50-400 ng/ml) were tested (data not shown), the maximal effect was observed at a concentration of $200 \mathrm{ng} / \mathrm{ml}$. This concentration was thus used in further experiments. We then asked whether BMP2, a member of the DPP class and thus a distant relative of BMP7, also affected testicular cell proliferation. To answer this question, we treated the in vitro cultured testis fragments with $200 \mathrm{ng} / \mathrm{ml}$ BMP 2 in the presence or absence of FSH. A significant increase of $\left[{ }^{3} \mathrm{H}\right]$-thymidine incorporation was observed when both BMP2 and FSH were present in the medium, thereby indicating that both BMP2 and BMP7

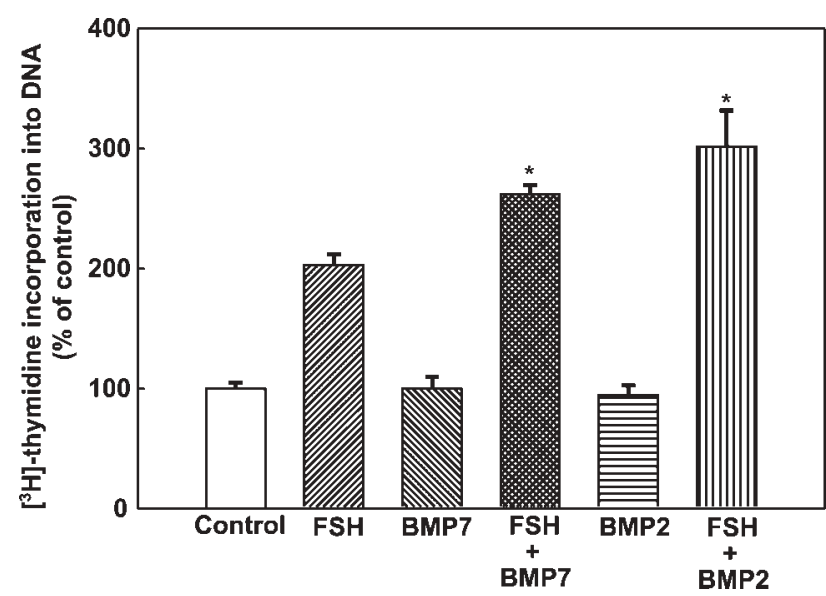

Figure 1 Effect of rh BMP7 and rh BMP2 with and without FSH on $\left[{ }^{3} \mathrm{H}\right]$-thymidine incorporation by testicular fragments from 7-day-old mice. Fragments were cultured for 3 days in the presence or absence of oFSH $(20 \mathrm{ng} / \mathrm{ml})$ and BMP7 or BMP2 (each at $200 \mathrm{ng} / \mathrm{ml}$ ) and eventually labelled with $\left[{ }^{3} \mathrm{H}\right]$-thymidine for $5 \mathrm{~h}$. $\left[{ }^{3} \mathrm{H}\right]$-thymidine incorporation into DNA was measured as described in Materials and methods. Each bar represents the mean \pm S.E.M. of three or more independent experiments, each with triplicate assays. Difference between treatments: FSH vs control, $P<0.01$; BMP7 vs control, $P>0.05$; BMP2 vs control, $P>0.05 ; \mathrm{FSH}+\mathrm{BMP} 7$ vs FSH, $P<0.01 ; \mathrm{FSH}+\mathrm{BMP} 2$ vs $\mathrm{FSH}, P<0.001$. Asterisks indicate significant difference with $\mathrm{FSH}$ alone. cooperate with FSH in promoting cell division in the prepuberal testis.

\section{Morphological analysis of BrdU-labelled testis fragments from 7-day-old mice}

We then addressed the question of which testicular cell type proliferated in response to different treatments by histochemical analysis of testicular fragments that had been labelled with BrdU at the end of a 3-day culture period in the presence or absence of either BMP2 or BMP7, with or without FSH. Within the seminiferous epithelium, Sertoli cells and spermatogonia were identified by their morphology, as described in Materials and methods. The treatment of BMP2 together with FSH elicited a significant increase in proliferating spermatogonia when compared with FSH alone, but had no effect on Sertoli cell proliferation (Fig. 2A-C). By contrast, the number of BrdU-labelled Sertoli cells was markedly enhanced by treatment with BMP7 and FSH, when compared with the gonadotrophin alone (Fig. 2A-D). It is noteworthy that there was no significant difference in the number of labelled spermatogonia between the FSH-treated fragments and the FSH plus BMP7-treated samples. We therefore concluded that, either directly or indirectly, BMP2 and BMP7 act, at the onset of spermatogenesis, to modulate spermatogonia and Sertoli cell proliferation respectively.

\section{Activin/BMP receptor expression in purified spermatogonia and Sertoli cells}

The fact that the main cell target of BMP7 was different from that of BMP2 suggested that at least two distinct signalling pathways, likely to be mediated by different BMP receptor type II and I complexes, may exist. We therefore investigated the expression of these receptors in highly purified populations of spermatogonia and Sertoli cells isolated from 7-day-old mouse testis. To this end, we analysed the mRNA expression of ActRIIA, ActRIIB, ActRIA, ActRIB and BMPRIA by ribonuclease protection assay (RPA) (Fig. 3A and B). ActRIIA transcripts were not detected in either germ cells or somatic cells, but ActRIIB, ActRIA, ActRIB and BMPRIA mRNAs were found in both cell types. The comparison of expression patterns in Fig. 3B shows that spermatogonia and Sertoli cells displayed similar levels of ActRIIB, ActRIA and ActRIB. By contrast, the BMPRIA expression of spermatogonia was lower than that of Sertoli cells.

We then extended the expression analysis of type II receptors to BMPRII, which forms an active receptor complex mediating BMP signalling, by examining germ cells at different steps of differentiation, as well as Sertoli cells (Fig. 4). Northern blotting analyses of Sertoli cells isolated from 7- and 14-day-old animals (not shown) revealed the presence of two major transcripts: a doublet of $9-10 \mathrm{~kb}$, and a shorter transcript 
A

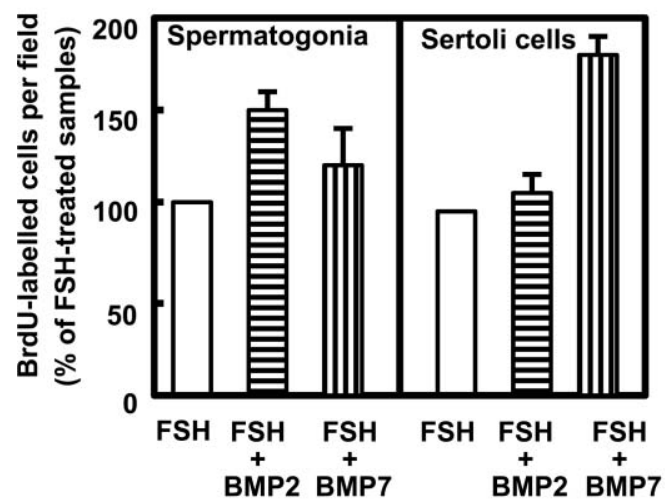

C

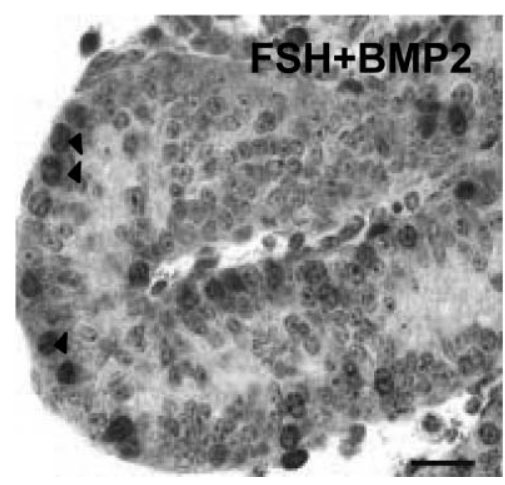

B

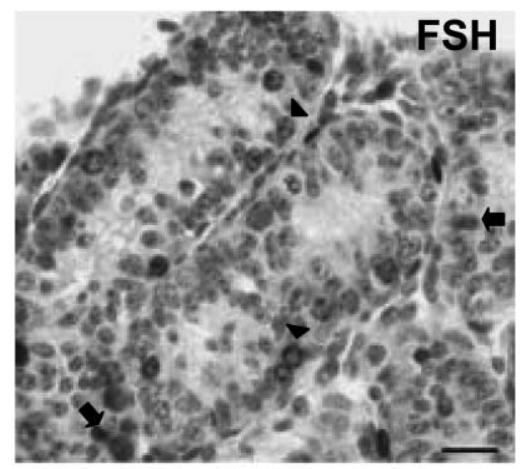

D

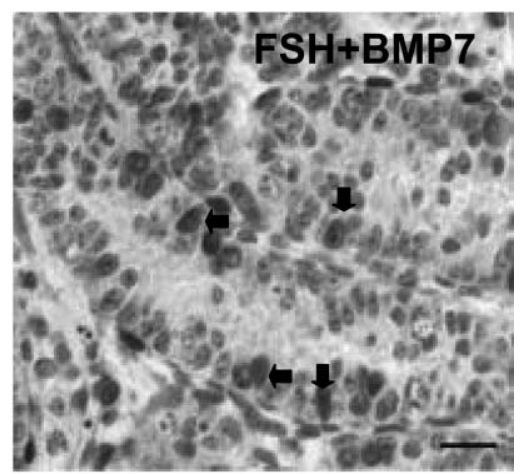

Figure 2 Stimulation of spermatogonia and Sertoli cell proliferation by BMP2 $(200 \mathrm{ng} / \mathrm{ml})$ and BMP7 $(200 \mathrm{ng} / \mathrm{ml})$ after 3-day culture of testis fragments in the presence of FSH $(20 \mathrm{ng} / \mathrm{ml})$. BrdU labelling was performed during the last $5 \mathrm{~h}$ of culture. (A) Number of BrdUlabelled spermatogonia and Sertoli cells per field $\left(250000 \mu \mathrm{m}^{2}\right)$. Each bar represents the mean \pm S.E.M. of three independent experiments. FSH + BMP2 vs FSH, $P<0.001 ; \mathrm{FSH}+\mathrm{BMP7}$ vs FSH $P<0.001$. (B-D) Photomicrographs of histological sections of testis fragments cultured in the presence of B, FSH; C, FSH + BMP2; and D, FSH + BMP7. Sections were immunostained with anti-BrdU as described in Materials and methods. Note BrdU-labelled Sertoli cells (arrows) and spermatogonia (arrowheads). Bar, $20 \mu \mathrm{m}$.

A

Spermatogonia Sertoli cells

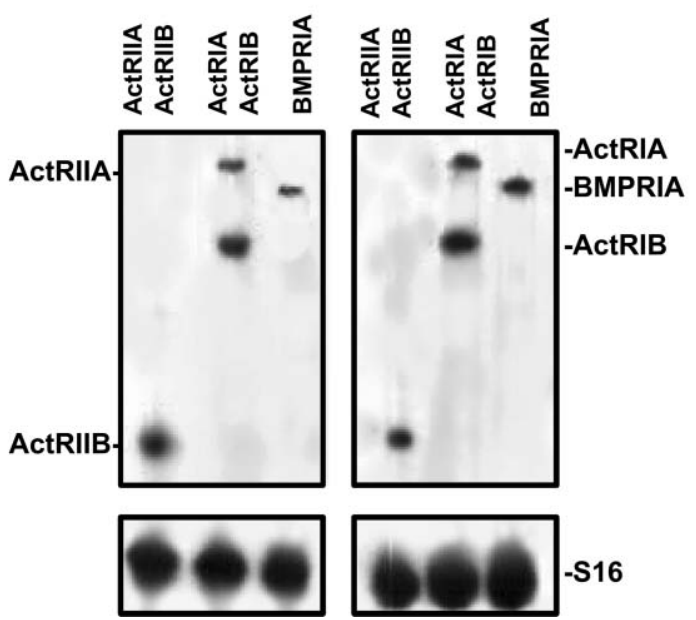

B

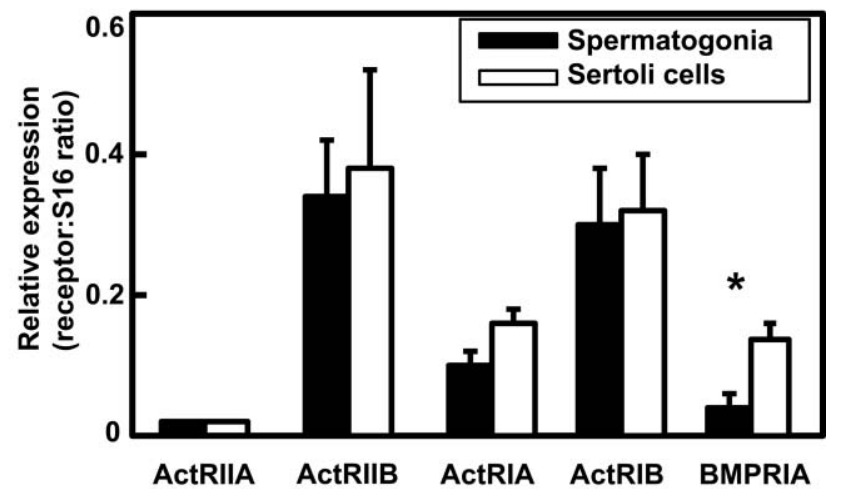

Figure 3 RNase protection analysis of activin/BMP receptor expression in spermatogonia and Sertoli cells. (A) An amount of $20 \mu \mathrm{g}$ of total RNA was hybridized with ActRIIA + ActRIIB riboprobes (lane 1), ActRIA + ActRIB (lane 2) and BMPRIA (lane 3). The data are representative of three independent experiments. S16 was used as RNA quantity control. (B) The levels of activin/BMP receptor mRNA were quantified individually by densitometric scanning of the autoradiograms, normalized to the content of S16 and expressed as arbitrary densitometric units. Histograms represent the mean \pm S.E.M. of receptor/S16 ratios obtained in three independent experiments. The asterisk indicates a significant difference $(P<0.05)$ between the two cell types. 


\section{Northern analysis of BMPRII}

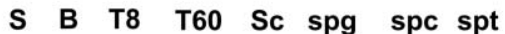
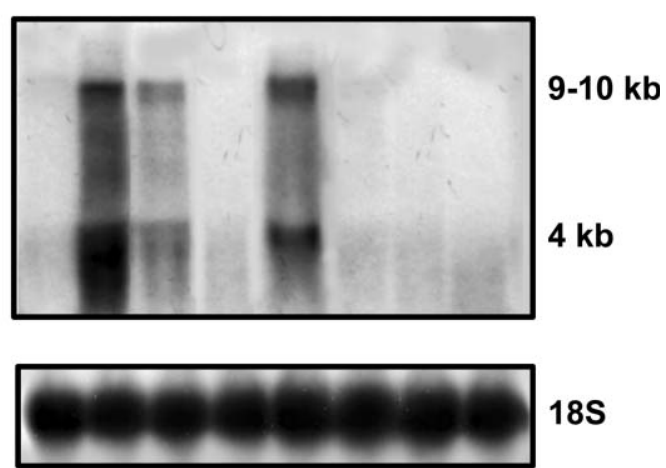

$18 S$

Figure 4 Northern blot analysis of BMP receptor type II (BMPRII) expression in spleen (S), brain (B), testis from 8-day-old (T8) and adult mice (T60), Sertoli cells (Sc), spermatogonia (spg), primary spermatocytes (spc) and round spermatids (spt). Each lane was loaded with $20 \mu \mathrm{g}$ total RNA. Equivalent loading was confirmed by hybridization with a ribosomal $18 \mathrm{~S}$ cDNA probe.

of approximately $4 \mathrm{~kb}$, as a broad band. A similar expression pattern was found in the adult brain (as positive control) and in the testis from 8-day-old mice. By contrast, purified populations of germ cells, including type A spermatogonia, pachytene spermatocytes and round spermatids, besides spleen (as negative control), showed no evidence of BMPRII mRNA. Of interest, BMPRII expression was undetectable also in the adult testis.

\section{Developmental expression of activin/BMP receptors in mouse testis}

To determine whether activin/BMP receptors are developmentally regulated during postnatal testis development, the expression pattern of type II and type I receptors was first studied by RPA, using total RNA isolated from testes of prepuberal (7-day-old) and late puberal (30-day-old) mice (Fig. 5A). In line with the observations on isolated somatic and germ cells, ActRIIA and ActRIIB showed an opposite developmental pattern, ActRIIA being expressed only at 30 days and ActRIIB mainly at 7 days. ActRIA, ActrRIB and BMPRIA were constantly present at both ages. We then asked whether a development-related change occurred in the expression pattern of different transcripts for each receptor. We therefore performed Northern blotting using total RNA from testes of mice from 5 to 60 days after birth (a.b.). Hybridization with a probe specific to ActRIIA revealed two transcripts of 6 and $3 \mathrm{~kb}$ respectively (Fig. 5B). The $6 \mathrm{~kb}$ transcript was less abundant and more weakly expressed in all infant/juvenile stages examined, and absent in the adult gonad. The $3 \mathrm{~kb}$ was barely expressed during the first week of testis development, consistent with its undetectable levels in isolated spermatogonia and Sertoli cells, but increased with age,
A

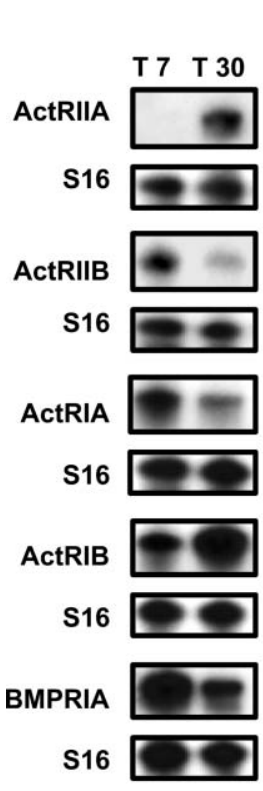

B

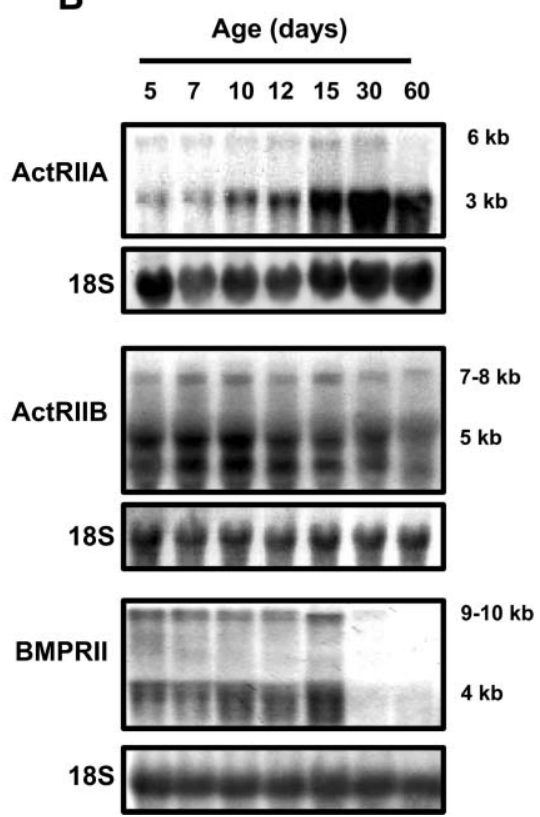

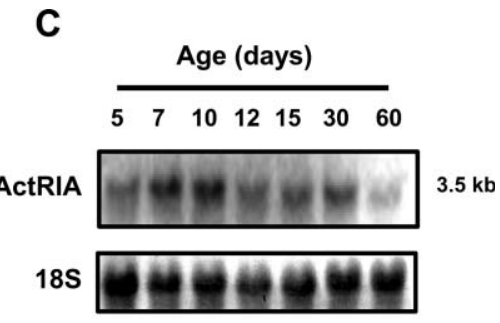
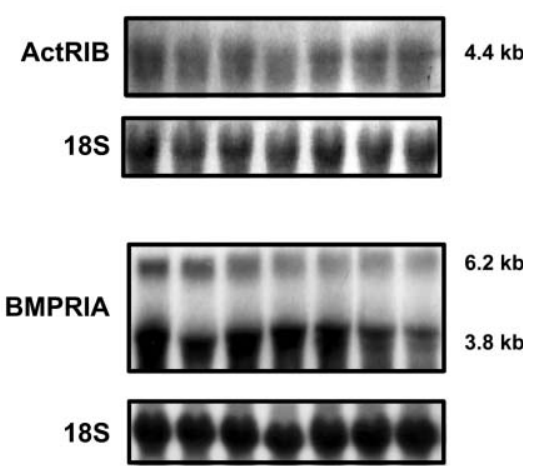

Figure 5 Developmental expression of activin/BMP receptors type II and type I in mouse testis. (A) RNase protection analysis in prepuberal (T7) and late puberal (T30) testis. S16 was used as RNA quantity control. (B) Total RNA (20 $\mu \mathrm{g}$ ) was prepared from mouse testis at different ages from 5 to 60 days a.b. and analysed by Northern blot hybridization with ActRIIA, ActRIIB and BMPRII cDNA probes. (C) Northern blotting using ActRIA, ActRIB and BMPRIA cDNA probes. The ages were the same as in panel B. Equivalent loading was confirmed by hybridization with a ribosomal $18 \mathrm{~S}$ cDNA probe (B and C). 
starting on day 12. When the filter was hybridized with a cDNA probe specific for ActRIIB, three mRNA distinct species were detected (Fig. 5B), the upper band being a doublet of approximately $7-8 \mathrm{~kb}$ and the other two of 5 and $4 \mathrm{~kb}$ respectively. The $5 \mathrm{~kb}$ was the predominant form of ActRIIB mRNA in the testis at all ages. All three ActRIIB transcripts had similar developmental patterns: they were highly expressed during the first 10-12 days of testis development, and declined thereafter. The signal in the adult was very weak. The localization of BMPRII on Sertoli cells isolated from 7- and 14-day-old animals prompted us to explore a possible correlation between the expression of BMPRII mRNA and the peculiar proliferation kinetics of these cells. Interestingly, BMPRII was strongly expressed from as early as 5 days a.b. for the duration of the first 2 weeks, and subsequently became undetectable by day 30 a.b (Fig. 5B). There were at least two BMPRII messages, with a similar relative abundance at all the ages examined, in agreement with results reported above (Fig. 4).

Northern blotting analysis of type I receptor detected the presence of a $3.5 \mathrm{~kb}$ ActRIA transcript (Fig. 5C), whose levels of expression increased during the first week of postnatal life, peaked in the 7-10-day interval, and eventually decreased after puberty. The fact that the level of ActRIA mRNA in the adult was negligible suggests that the role of this receptor was apparently limited to the initial phases of postnatal testis development. The analysis of ActRIB expression revealed a broad mRNA band of approximately $4.4 \mathrm{~kb}$ (Fig. 5C), which remained stable at all the time points examined. Northern blot analysis of BMPRIA (Fig. 5C) revealed two messages of 6.2 and $3.8 \mathrm{~kb}$, the shorter one being the predominant form at all ages. It is noteworthy that BMPRIA mRNA expression pattern correlated well with that of BMPRII: it was high in the newborn mice and during the first 2 weeks of postnatal development, and decreased thereafter.

\section{Discussion}

The findings of this study demonstrate that BMP7 and BMP2 act as proliferative signals upon Sertoli cells and spermatogonia during the early postnatal development of mouse testis. Our results shed new light on the biological activities of growth factors of the TGF $\beta$ superfamily that are produced locally within the testis and contribute to gonadal growth control. Indeed, both BMP2 and BMP7 are physiologically expressed in the testis (7). In particular, BMP7 signal has been found to be associated with spermatogonia and primary spermatocytes during early puberty by in situ hybridization (7). In accordance with the hypothesis that BMP7 is relevant to a paracrine mechanism, we show here that BMP7 exerts a stimulatory effect upon the proliferation of Sertoli cells, though not of spermatogonia, in 7-day-old mouse testicular fragments. However, the possibility that the observed effect could be indirect cannot be ruled out. One of the advantages of testis organ cultures compared with isolated cells is that cell-to-cell interactions and testicular architecture are well maintained, thus allowing better investigation of issues such as the paracrine regulation of Sertoli cell and spermatogonia proliferation. In this view, we have observed the effect of BMP7 and BMP2 only in the presence of $\mathrm{FSH}$, again pointing to the concept that these factors function as fine modulators of this gonadotrophin in locally regulating testicular cell proliferation in vitro. Our observation suggests potential in vivo cross-talk mediated by the secretion of BMP7 by spermatogonia and affecting Sertoli cell function. Attempts have been made to investigate the BMP7 role in testis physiology by a genetic approach. Interestingly, $B M P 7^{+/-}: B M P 8 a^{-/-}$double mutants showed more pronounced testis degeneration phenotype than homozygous $B M P \& a$ from the age of 4 weeks (7). In addition, as BMP $8 b$ homozygous mutants also display a defect in germ cell proliferation and differentiation (8), these data taken together emphasize the importance of BMP7, BMP8A and BMP8B, all members of the 60A subgroup within the BMP family, as fine regulators of both the onset and the maintenance of spermatogenesis.

The DPP class, another well-characterized subgroup of the large BMP family, includes BMP2 and BMP4. These factors share a $92 \%$ sequence identity at the amino acid level in the mature region, and both are expressed in the testis (7). Indeed, Sertoli cells have been recently shown to be the site of expression of BMP4, which was limited to the first week of postnatal life in the mouse (37). Although no evidence is yet available on the localization of BMP2 in young and adult testes, we report here that BMP2 increases spermatogonia proliferation without affecting Sertoli cell mitotic activity. In view of the close homology between BMP2 and BMP4, this finding highlights the significant role of the members of this BMP class in the local regulation of germ cell function. This observation is in keeping with the fact that BMP4 has a stimulatory effect on $\left[{ }^{3} \mathrm{H}\right]$-thymidine incorporation by spermatogonia isolated from 4 and 7-day-old mice (37). By contrast, BMP4 has a negative effect on the maintenance of adult spermatogonial stem cells in vitro (38), whereas substantial in vivo and in vitro evidence indicates that both BMP2 and BMP4 are required for primordial germ cell generation in the embryo (11-13, 39). Taken together, these observations lend support to the idea that a given signalling molecule may affect normal cell differentiation in various stages of spermatogenesis depending on when and where it is present. However, a number of findings supports the involvement of more than one regulatory factor in spermatogenesis. In this context we, as well as other authors, have previously demonstrated that activin, another member of TGF $\beta$ superfamily, maintains mitotic potentiality of Sertoli cells in a 
defined phase of their maturation process, when the proliferative activity of these cells is approaching its end $(21,40,41)$.

It is interesting to note that both BMP7 and activin are also involved in the paracrine control of ovarian function, and in particular granulosa cell function, including a stimulatory effect upon mitotic activity $(42,43)$.

The present observation that both spermatogonia and Sertoli cells express type I and type II BMP/activin receptors provides additional evidence for the physiological relevance of the factors belonging to the BMP family during early postnatal testicular maturation. We demonstrate that apart from ActRIIA, which is not expressed in both cell types, and BMPRII, which is absent in spermatogonia, ActRIIB, ActRIA, ActRIB and BMPRIA are all expressed in isolated spermatogonia and Sertoli cells. This, in turn, suggests that the biological effects of BMP2 and BMP7 on spermatogonia and Sertoli cell proliferation are mediated by several possible combinations of receptor complexes. However, as the functional specificity of these complexes has not yet been assessed, their functional interpretation is impossible. In fact, it is unclear whether BMPs of different classes share the same receptor complexes. Indeed, previous reports have demonstrated that both BMP2 and BMP7 bind BMPRII with BMPRIA, BMPRIB and ActRIA, thereby inducing a transcriptional response (44). However, the same factors also elicit biological responses by binding ActRIIA and ActRIIB (45). It is therefore likely that specific interactions are achieved during testis development by means of a fine spatial and temporal regulation of both ligand and receptor isoform expression. Indeed, we found in this study that Sertoli cells specifically express BMPRII and that the temporal distribution of this receptor during the first 2 weeks of postnatal testis development correlates with the modulating action of BMP7 upon Sertoli cell proliferation. By contrast, the ActRIIA expression pattern in the developing testis was found to be very different from that of BMPRII, in so far as it increased with age and was present in meiotic and postmeiotic cells (Ref. 18 and our unpublished data). Thus, taken as a whole, the data presented in this study suggest that BMP7 exerts a proliferative effect on Sertoli cells via BMPRII and/or ActRIIB as type II receptors in a specific period of testis growth. In this respect, it is interesting to note that the age-related expression of ActRIIA in Sertoli cells coincides with a precise developmental interval of the proliferative effect of activin on these cells (22), indicating that the TGF $\beta$ superfamily signalling is regulated in a time- and space-dependent manner during testis development in the rat. In the present study, we observed regulated expression of several type I BMP/activin receptors, including BMPRIA; the developmental profile of BMPRIA is intensely expressed during the first 10-15 days of postnatal life and decreases thereafter, thus overlapping with that of BMPRII. This finding supports the hypothesis that BMP7 affects Sertoli cell division in immature mouse by signalling through a BMPRII/BMPRIA receptor complex. Accordingly, BMPRIA showed much higher levels of expression in Sertoli cells than in spermatogonia. BMPRIB was not analysed in this study because, although it was shown in cotransfection experiments that it can function as BMP receptor, there is no evidence of its expression either in the fetal (34) or in the adult testis (46). On the contrary, BMPRIB was recently shown to mediate signalling of Müllerian inhibiting substance (MIS), which is not a BMP (47). It is noteworthy that the expression of other components involved in the BMP signalling pathway, including follistatin, a weak BMP interacting protein (40), BAMBI, a non-signalling type I pseudoreceptor (48), and Smad 1, a downstream transducer (49), have been shown to be regulated within developing male germ cells. Follistatin, in particular, has been shown to function either as antagonist (16) or agonist (50) of BMP7, depending on the developmental system.

Therefore, these data, taken as a whole, highlight the need to understand the precise function of the potential regulators of the TGF $\beta$ superfamily members during testis development.

\section{Acknowledgements}

We are grateful to Prof. Franco Mangia for critical reading of the manuscript and to Mrs Tiziana Menna for her technical assistance. We thank NHPP, NIDDK and Dr A F Parlow for providing oFSH, and the Creative Biomolecules and Genetics Institute for providing rh BMP7 and BMP2 respectively. This work was supported by grants from MIUR, ASI and Cofin 2003 to C B; and from MIUR Cofin 2001, Department of Health Special Program 2001, Department of Work 1999 and the Excellence Center for Biology and Molecular Medicine (BEMM) of the University of Rome 'La Sapienza' to M S.

\section{References}

1 Orth JM, Gunsalus GL \& Lamperti AA. Evidence from Sertoli celldepleted rats indicates that spermatid number in adults depends on number of Sertoli cells produced during perinatal development. Endocrinology $1988 \mathbf{1 2 2} 787-794$.

2 Hogan BL. Bone morphogenetic proteins: multifunctional regulators of vertebrate development. Genes and Development $1996 \mathbf{1 0}$ $1580-1594$.

3 Zhao GQ. Consequences of knocking out BMP signaling in the mouse. Genesis $20033543-56$.

4 Israel DI, Nove J, Kerns KM, Kaufman RJ, Rosen V, Cox KA \& Wozney JM. Heterodimeric bone morphogenetic proteins show enhanced activity in vitro and in vivo. Growth Factors 199613 291-300.

5 Suzuki A, Kaneko E, Maeda J \& Ueno N. Mesoderm induction by BMP-4 and -7 heterodimers. Biochemical and Biophysical Research Communications $1997232153-156$.

6 Zhao GQ \& Hogan BL. Evidence that mouse Bmp8a (Op2) and Bmp8b are duplicated genes that play a role in spermatogenesis 
and placental development. Mechanisms of Development 199657 159-168.

7 Zhao GQ, Chen YX, Liu XM, Xu Z \& Qi X. Mutation in Bmp7 exacerbates the phenotype of Bmp8a mutants in spermatogenesis and epididymis. Developmental Biology $2001240212-222$.

8 Zhao GQ, Deng K, Labosky PA, Liaw L \& Hogan BL. The gene encoding bone morphogenetic protein $8 \mathrm{~B}$ is required for the initiation and maintenance of spermatogenesis in the mouse. Genes and Development $1996101657-1669$.

9 Zhao GQ, Liaw L \& Hogan BL. Bone morphogenetic protein 8A plays a role in the maintenance of spermatogenesis and the integrity of the epididymis. Development $1998 \mathbf{1 2 5} 1103-1112$.

10 Ying Y, Liu XM, Marble A, Lawson KA \& Zhao GQ. Requirement of Bmp8b for the generation of primordial germ cells in the mouse. Molecular Endocrinology 200014 1053-1063.

11 Lawson KA, Dunn NR, Roelen BA, Zeinstra LM, Davis AM, Wright CV, Korving JP \& Hogan BL. Bmp4 is required for the generation of primordial germ cells in the mouse embryo. Genes and Development 199913 424-436.

12 Ying Y, Qi X \& Zhao GQ. Induction of primordial germ cells from murine epiblasts by synergistic action of BMP4 and BMP8B signaling pathways. PNAS 200198 7858-7862.

13 Ying Y \& Zhao GQ. Cooperation of endoderm-derived BMP2 and extraembryonic ectoderm-derived BMP4 in primordial germ cell generation in the mouse. Developmental Biology 2001232 484-492.

14 Chang H, Brown CW \& Matzuk MM. Genetic analysis of the mammalian transforming growth factor-beta superfamily. Endocrine Reviews 200223 787-823.

15 Greenwald J, Groppe J, Gray P, Wiater E, Kwiatkowski W, Vale W \& Choe S. The BMP7/ActRII extracellular domain complex provides new insights into the cooperative nature of receptor assembly. Molecular Cell 200311 605-617.

16 Yamashita H, ten Dijke P, Huylebroeck D, Sampath TK, Andries M, Smith JC, Heldin CH \& Miyazono K. Osteogenic protein-1 binds to activin type II receptors and induces certain activin-like effects. Journal of Cell Biology 1995130 217-226.

17 ten Dijke P, Yamashita H, Sampath TK, Reddi AH, Estevez M, Riddle DL, Ichijo H, Heldin $\mathrm{CH}$ \& Miyazono K. Identification of type I receptors for osteogenic protein-1 and bone morphogenetic protein-4. Journal of Biological Chemistry 1994269 16985-16988.

18 de Winter JP, Themmen APN, Hoogerbrugge JW, Klaij IA, Grootegoed JA \& de Jong FH. Activin receptor mRNA expression in rat testicular cell types. Molecular and Cellular Endocrinology 1992 $831-8$.

19 Kaipia A, Parvinen M \& Toppari J. Localization of activin receptor $\left(\right.$ ActRIIB $\left._{2}\right)$ mRNA in rat seminiferous epithelium. Endocrinology $1993132477-479$.

20 Cameron VA, Nishimura E, Mathews LS, Lewis KA, Sawcenko PE \& Vale W. Hybridization histochemical localization of activin receptor subtypes in rat brain, pituitary, ovary, and testis. Endocrinology $1994134799-808$.

21 Boitani C, Stefanini M, Fragale A \& Morena AR. Activin stimulates Sertoli cell proliferation in a defined period of rat testis development. Endocrinology $19951365438-5444$.

22 Fragale A, Puglisi R, Morena AR, Stefanini M \& Boitani C. Age-dependent activin receptor expression pinpoints activin A as a physiological regulator of rat Sertoli cell proliferation. Molecular Human Reproduction 20017 1107-1114.

23 Boitani C, Politi MG \& Menna T. Spermatogonial cell proliferation in organ culture of immature rat testis. Biology of Reproduction $199348761-767$.

24 Huckins C \& Oakberg EF. Morphological and quantitative analysis of spermatogonia in mouse testes using whole mounted seminiferous tubules I. The normal testes. Anatomical Record 1978192 519-528.

25 Russell LD, Ettlin RA, Hikim APS \& Clegg ED. Staging for laboratory species. In Histological and histopathological evaluation of the testis, ch 4, pp 119-161. Eds LD Russell, RA Ettlin, APS Hikim \& ED Clegg. Clearwater, FL: Cache River Press, 1990.

26 Morena AR, Boitani C, Pesce M, De Felici M \& Stefanini M. Isolation of highly purified type A spermatogonia from prepubertal rat testis. Journal of Andrology 199617 708-717.

27 Puglisi R, Tramer F, Panfili E, Micali F, Sandri G \& Boitani C. Differential splicing of the phospholipid hydroperoxide glutathione peroxidase gene in diploid and haploid male germ cells in the rat. Biology of Reproduction $2003 \mathbf{6 8} 405-411$.

28 Scarpino S, Morena AR, Petersen C, Froysa B, Soder O \& Boitani C. A rapid method of Sertoli cell isolation by DSA lectin, allowing mitotic analyses. Molecular and Cellular Endocrinology $1998 \mathbf{1 4 6}$ $121-127$.

29 Chirgwin JM, Przybyla AEMRJ \& Rutter WJ. Isolation of biologically active ribonucleic acid from sources enriched in ribonuclease. Biochemistry $1979185294-5299$.

30 Mathews LS \& Vale W. Expression cloning of activin receptor, a predicted transmembrane serine kinase. Cell $1991 \mathbf{6 5}$ 973-982.

31 Attisano L, Wrana JL, Cheifetz S \& Massaguè J. Novel activin receptor: distinct genes and alternative mRNA splicing generate a repertoire of serine/threonine kinase receptors. Cell $1992 \mathbf{6 8}$ $97-108$.

32 Ebner R, Chen RH, Lawler S, Zioncheck T \& Derynck R. Determination of type I receptor specificity by the type II receptors for TGF-beta or activin. Science 1993262 900-902.

33 Verschueren K, Dewulf N, Goumans MJ, Lonnoy O, Feijen A, Grimsby S, Vandi SK, ten Dijke P, Moren A \& Vanscheeuwijck P. Expression of type I and type IB receptors for activin in midgestation mouse embryos suggests distinct functions in organogenesis. Mechanisms of Development 199552 109-123.

34 Dewulf N, Verschueren K, Lonnoy O, Moren A, Grimsby S, Vande SK, Miyazono K, Huylebroeck D \& ten Dijke P. Distinct spatial and temporal expression patterns of two type I receptors for bone morphogenetic proteins during mouse embryogenesis. Endocrinology $19951362652-2663$.

35 Beppu H, Minowa O, Miyazono K \& Kawabata M. cDNA cloning and genomic organization of the mouse BMP type II receptor. Biochemical and Biophysical Research Communications 1997235 499-504.

36 Wagner M \& Perry RP. Characterization of the multigene family encoding the mouse S16 ribosomal protein: strategy for distinguishing an expressed gene from its processed pseudogene counterparts by an analysis of total genomic DNA. Molecular and Cellular Biology 19855 3560-3576.

37 Pellegrini M, Grimaldi P, Rossi P, Geremia R \& Dolci S. Developmental expression of BMP4/ALK3/SMAD5 signaling pathway in the mouse testis: a potential role of BMP4 in spermatogonia differentiation. Journal of Cell Science $20031163363-3372$.

38 Nagano M, Ryu BY, Brinster CJ, Avarbock MR \& Brinster RL. Maintenance of mouse male germ line stem cells in vitro. Biology of Reproduction 200368 2207-2214.

39 Pesce M, Gioia KF \& De Felici M. Derivation in culture of primordial germ cells from cells of the mouse epiblast: phenotypic induction and growth control by Bmp4 signalling. Mechanisms of Development $200211215-24$.

40 Meehan T, Schlatt S, O’Bryan MK, de Kretser DM \& Loveland KL. Regulation of germ cell and Sertoli cell development by activin, follistatin and FSH. Developmental Biology $2000220225-237$.

41 Buzzard JJ, Farnworth PG, de Kretser DM, O'Connor AE, Wreford NG \& Morrison JR. Proliferative phase Sertoli cells display a developmentally regulated response to activin in vitro. Endocrinology $2003144474-483$.

42 Li R, Phillips DM \& Mather JP. Activin promotes ovarian follicle development in vitro. Endocrinology 1995136 849-856.

43 Lee WS, Otsuka F, Moore RK \& Shimasaki S. Effect of bone morphogenetic protein-7 on folliculogenesis and ovulation in the rat. Biology of Reproduction 200165 994-999.

44 Liu F, Ventura F, Doody J \& Massaguè J. Human type II receptor for bone morphogenetic proteins (BMPs): extension of the two kinase 
receptor model to the BMPs. Molecular and Cellular Biology 1995 15 3479-3486.

45 Macias-Silva M, Hoodless PA, Tang SJ, Buchwald M \& Wrana JL. Specific activation of Smad1 signaling pathways by the BMP7 type I receptor, ALK2. Journal of Biological Chemistry 1998273 25628-25636.

46 ten Dijke $\mathrm{P}$, Yamashita $H$, Ichijo $H$, Franzen $\mathrm{P}$, Laiho $\mathrm{M}$, Miyazono K \& Heldin C-H. Characterization of type I receptors for transforming growth factor- $\beta$ and activin. Science 1994264 $101-104$

47 Clarke TR, Hoshiya Y, Yi SE, Liu X, Lyons KM \& Donahoe PK. Mullerian inhibiting substance signaling uses a bone morphogenetic protein (BMP)-like pathway mediated by ALK2 and induces SMAD6 expression. Molecular Endocrinology 200115 946-959.

48 Loveland KL, Bakker M, Meehan T, Christy E, Von Schonfeldt V, Drummond A \& de Kretser D. Expression of BAMBI is widespread in juvenile and adult rat tissues and is regulated in male germ cells. Endocrinology $2003 \mathbf{1 4 4} 4180-4186$.

49 Zhao GQ \& Hogan BL. Evidence that mothers-against-dpp-related 1 (Madr1) plays a role in the initiation and maintenance of spermatogenesis in the mouse. Mechanisms of Development 199761 $63-73$.

50 Amthor H, Christ B, Rashid-Doubell F, Kemp CF, Lang E \& Patel K. Follistatin regulates bone morphogenetic protein-7 (BMP-7) activity to stimulate embryonic muscle growth. Developmental Biology 2002243 115-127.

Received 14 March 2004

Accepted 16 June 2004 